\title{
Crustacean and rotifer seasonality in a Mediterranean temporary pond with high biodiversity (Lavajo de Abajo de Sinarcas, Eastern Spain)
}

\author{
María Sahuquillo and Maria Rosa Miracle
}

Departament de Microbiologia i Ecologia, Institut Cavanilles de Biodiversitat i Biologia Evolutiva, Universitat de València, E-46100 Burjassot, València, Spain.

*Corresponding authors: maria.sahuquillo@uv.es; rosa.miracle@uv.es

Received: 20/12/08

Accepted: 20/6/09

\begin{abstract}
Crustacean and rotifer seasonality in a Mediterranean temporary pond with high biodiversity (Lavajo de Abajo de Sinarcas, Eastern Spain)

A follow-up study was made of planktonic and periphytic crustaceans and rotifers during two hydroperiods of consecutive years in a Mediterranean temporary pond. The pond is relatively large with quite long hydroperiods in wet years (6-8 months) and it has a very rich community (4 large branchiopods, 12 cladocerans, 9 copepods, 36 rotifers). Three phases in faunal composition, quite consistent from year to year, were distinguished: (1) Filling phase in autumn-winter is dominated by anostracans (endemic Branchipus cortesi, with low proportions of Branchipus schaefferi) and diaptomids, two univoltine species (Hemidiaptomus ingens inermis, Diaptomus cyaneus intermedius) and one multivoltine (Mixodiaptomus laciniatus atlantis). (2) Middle phase in spring dominated by cladocerans (Ceriodaphnia n.sp., Simocephalus vetulus, Ephemeroporus pinthonicus, Chydorus sphaericus, Alona azorica) in this phase is also abundant the conchostracan Maghrebestheria maroccana and the notostracan Triops cancriformis. A shift toward insects occurs in the later part of this phase. (3) Desiccation phase in summer with lower diversity (Moina micrura, Alona rectangula and cyclopoids). Rotifers showed a low contribution to biomass and were more important in the middle phase. These phases are also marked by an increase of nutrients and phytoplankton chlorophyll in the filling and desiccation phases and a decrease of these variables in the middle phase, resulting in phytoplankton clearance and greater water transparency, concurrent with macrophyte growth. Interannual variability was outstanding in shaping these phases. The year 2007 was preceded by a wetter autumn, whereas 2008 was preceded by a very dry autumn thus, in this second year the main hydroperiod was shorter and the first phase was merged with the middle phase. In this shorter hydroperiod the open water microinvertebrate community reached lower biomass but attained a similar diversity since rotifers became relatively more abundant and richer in species than in the 2007 main hydroperiod, when the community was fully dominated by crustaceans.
\end{abstract}

Key words: Mediterranean temporary ponds, ecological succession, hydroperiod, large branchiopoda, Hemidiaptomus, cladocerans, rotifers.

\section{RESUMEN}

Estacionalidad de los crustáceos y rotíferos en una laguna temporal mediterránea con alta biodiversidad (Lavajo de Abajo de Sinarcas, Levante español

Se ha estudiado la estacionalidad de las comunidades de crustáceos y rotíferos planctónicos y perifíticos en una charca temporal mediterránea en varios hidroperiodos durante dos años consecutivos. La charca tiene una extensión relativamente grande con un hidroperiodo largo en años húmedos (7-8 meses) y alberga una gran riqueza de especies (4 grandes branquiópodos, 12 cladóceros, 9 copépodos, 36 rotíferos). Basándonos en los cambios en la composición de esta fauna, se diferencian tres fases que se repiten de año en año, estas fases son: (1) Fase de llenado en otoño-invierno, dominada por anostráceos (principalmente por el endémico Branchipus cortesi, con una baja proporción de Branchipus schaefferi) y diaptómidos, dos especies univoltinas (Hemidiaptomus ingens inermis y Diaptomus cyaneus intermedius) y una multivoltina (Mixodiaptomus laciniatus atlantis). (2) Fase intermedia en primavera, dominada por cladóceros (Ceriodaphnia n.sp., Simocephalus vetulus, Ephemeroporus pinthonicus, Chydorus sphaericus, Alona azorica), destacan también en esta fase la presencia del concostráceo Maghrebestheria maroccana y el notostráceo Triops cancriformis. Los rotíferos contribuyen poco a la biomasa y son algo 
más importantes en esta fase intermedia. En la última parte de esta fase se produce un cambio hacia una mayor presencia de insectos. (3) Fase de desecación en verano que corresponde con una menor diversidad (Moina micrura, Alona rectangula y ciclópidos). Las fases de llenado y desecación se caracterizan también por un aumento de nutrientes y clorofila fitoplantónica mientras que en la fase intermedia su concentración es menor, aumentando la transparencia del agua y el desarrollo de los macrófitos. La variabilidad interanual determina la configuración de estas fases. El año 2007 fue precedido por un otoño húmedo mientras que 2008 fue precedido por un otoño muy seco, por lo que en este segundo año el hidroperiodo principal fue muy corto fusionándose la primera fase con la intermedia y la biomasa de microinvertebrados en aguas abiertas fue mucho menor que en el hidroperiodo del 2007, sin embargo se alcanzaron valores similares de diversidad debido a una relativamente mayor abundancia y riqueza de especies de rotíferos con respecto al hidroperiodo del 2007, en el que dominaron plenamente los crustáceos.

Palabras clave: Charcas temporales mediterráneas, hidroperiodo, sucesión ecológica, grandes branquiopodos, Hemidiaptomus, cladóceros, rotíferos.

\section{INTRODUCTION}

Ponds have recently begun to receive increasing attention, one of the reasons being their exceptional contribution to biodiversity. Collectively, they support considerably more species than other freshwater water body types and often constitute biodiversity "hot spots" within a region or landscape (Céréghino et al., 2008; Thiéry, 1991). In the Mediterranean regions of Europe, temporary ponds have been identified as a priority in the EU Habitats Directive. They are of interest as habitats for rare species and constitute last refuges of ancient species. However, due to their temporality they have been largely modified, many have been drained, large peripheral parts of those that do not attain their maximum level every year have been converted into agricultural fields, others have been deepened to hold water permanently and nearly all are used and maintained for cattle watering. This implies that non-modified systems are very scarce.

Among the inhabitants of the ponds, crustaceans and rotifers play an important role especially at the first stages of colonization; many recent studies are based on extensive sampling campaigns covering wide areas and environmental gradients to study their distributions (Ebert \& Balko, 1987; Ripley \& Simovich, 2009; Alonso, 1998). However, as Fahd et al.,(2007) pointed out, studies in intensive samplings over a sin- gle or few ponds but covering different seasons (cumulative survey) are also required for accurate evaluations of zooplankton diversity and species richness Although good examples of this type of studies can be found (Lake et al., 1989; Lahr et al.,1999; Taylor \& Mahoney, 1990; Crosetti \& Margaritora, 1987; Tavernini et al., 2005; Boix et al., 2004), they are less frequent.

The present study is framed in the second approach and its specific objectives were to examine the zooplankton community of a Mediterranean temporary pond, "Lavajo de Abajo" of Sinarcas (Valencia, Spain), along the hydroperiod and to examine some trends in the species composition and seasonal changes of the zooplankton population in this habitat. This temporary pond is ideal for this purpose because: (1) The hydroperiod in Sinarcas pond is more or less predictable and in wet years is relatively long (6-8 months), although in dry years several discontinuous shorter hydroperiods are the rule. The pond is one of the largest in the Comunidad Valenciana (Miracle et al., 2008) and presents an important development of varied aquatic vegetation in spring. These characteristics have been pointed out by other studies as favourable conditions for high invertebrate species richness; in particular, the length of the hydroperiod (Mahoney et al., 1990; Serrano \& Fahd, 2005), as it implies more chances for species replacement in these fluctuating environments. (2) This pond can be identified as a refe- 
rence site much closer than others to the pristine state that can be expected in the temporary ponds of continental Mediterranean climate in open basins. This temporary pond has attracted interest due its particular and rich aquatic and amphibious flora with Isoetes velata (Mansanet \& Mateo 1978) and has been included in the Nature 2000 Network according to the EU 'Habitat Directive' (Laguna et al., 2003). During a previous extensive study of temporary ponds of the "Comunidad Valenciana", carried out in 2006-07 (Miracle et al., 2008), this pond stood out for its high large branchiopod richness. Samples taken in this pond since 1988 indicated the presence of a peculiar microinvertebrate fauna as well.

This work focuses on branchiopod, copepod, and rotifer temporal distribution in this temporary pond, which, despite being greatly endangered, still conserves characteristic complex species associations during the hydroperiods of 2007 and 2008. We will also highlight the high species richness observed since pond biodiversity has been recognized as a significant goal in present days, when so many habitats are threatened by human activity or climate change.

\section{METHODS}

\section{Study site}

"Lavajo de Abajo de Sinarcas" is a temporary pond of the municipality of Sinarcas, located at $869 \mathrm{~m}$ a.s.l. in the homonym basin, which is a natural depression made up of Plio-Quaternary siliciclastic deposits (rañas) lying on top of Miocenic sediments. "Lavajo" is one of the popular names given to steppic, endorheic or semiendorheic ponds, which are often connected to an aquifer to some extent. The Sinarcas pond lies on a relatively independent surface aquifer ("raña aquifer") easily replenished by precipitation. It occupies the centre of a flooded meadow, now partly transformed into agricultural fields (vineyards and cereals) and it is also used for sheep watering. It has a typical circular shape, which attained a maximum surface area of almost one hectare and a maximum depth of $1.5 \mathrm{~m}$ during the study period.
The shores slope varies smoothly, providing a wide shallow peripheral zone that is at the mercy of water level fluctuations.

Sinarcas has a continental Mediterranean climate, characterized by dry and hot summers, with the main rainfall occurring in autumn and spring and quite low winter temperatures with frequent night frost. Mean annual rainfall (years 1999-2008) was around $500 \mathrm{~mm}$ and monthly evapotranspiration rates ranged from $26 \mathrm{~mm}$ in December to $181 \mathrm{~mm}$ in July (monthly means, years 1999-2008, IVIA Irrigation Technology Service). The pond usually fills up in autumn and typically dries up in late summer, but it can have one or more dry spells in between, depending on annual rainfall.

Two kilometres from this temporary pond there is a second one, Lavajo de Arriba, which has been artificially deepened to maintain water and has become semi-permanent, becoming dry only in extremely arid years. The profile of the semipermanent pond shows an abrupt slope that forms a hollow in one of its sides, with a maximum depth of $2 \mathrm{~m}$, which drains water from the shallower shores so the shallow peripheral zone remains flooded only during short periods after episodes of heavy rain. Besides the general information as a priority habitat in Nature 2000 (Laguna et al., 2003), there are only references on its flora (Mansanet \& Mateo 1978; Mateo, 1983) and the findings of some interesting species in its shore (Valentin et al., 2007; Fos et al., 2008).

\section{Collection of samples}

A follow-up study was made of planktonic and periphytic crustaceans and rotifers in two consecutives years: (1) during a long hydroperiod (December 2006-July 2007), (2) during a shorter hydroperiod (March-August 2008) and (3) in September 2007 during a brief incidence of small land grooves refilling with rainwater in the deepest part of the pond basin. Furthermore, previous samples taken in various years mainly in spring since 1988, were also analysed.

Samples were taken from different mesohabitats, in the open waters of the central area, and in zones with macrophytes. Integral water sam- 
ples of the water column were taken, when possible, with a transparent tube $(5 \mathrm{~cm}$ internal diameter, 1 or $0.5 \mathrm{~m}$ long, depending on pond depth). Zooplankton was concentrated in situ by filtering water samples through a $30 \mu \mathrm{m}$ nytal mesh and fixed in $4 \%$ formalin. At least three tubes were taken at different points and integrated to get one composite sample. Two replicate quantitative zooplankton samples were collected every sampling date. In addition, zooplankton was collected in horizontal transects by towing a net of $45 \mu \mathrm{m}$. In the vegetated areas we generally took 3 qualitative samples by sweeping a $90 \mu \mathrm{m}$ hand-net at different locations near the shore and at some distance from it. The presence of large branchiopods (especially notostracans and conchostracans) was checked in very shallow shore areas by carrying out an exhaustive visual examination. All the material collected was fixed in $4 \%$ formaldehyde. For quantitative samples all specimens were identified and counted and results were expressed as individuals per litre. Length was also measured for each species and crustacean biomasses were calculated from published regression equations (length-dry weight, Bottrell et al., 1976, Dumont et al., 1975 or length-carbon regressions: Vasama \& Kankaala, 1990; Luokkanen, 1995. Rotifer carbon contents were obtained from Latja \& Salonen (1978) and Telesh, Rahkola \& Viljanen (1998). Dry weight of zooplankton was calculated assuming that the carbon content is $40 \%$ of dry weight. For net samples we counted sub-samples to obtain relative abundances, until no statistical variation was observed or no other new species were found. Additionally, the remaining material was examined at lower magnification to trace less abundant large-sized taxa.

Water samples were also taken in the open water for biological and chemical analyses and some limnological variables were determined in situ (temperature, oxygen, conductivity, $\mathrm{pH}$, maximum depth, vegetation cover, etc.). Turbidity, alkalinity, chlorophyll-a, total phosphorous and total nitrogen were determined following APHA (1992).

Daily rainfall and temperature data (Fig. 1), provided by Sinarcas Meteorological Station, were smoothed using a moving average of 10 days.

\section{Data analysis}

For each sampling date the Shannon diversity index $H^{\prime}$ (mean and variance) for cladocerans + copepods was estimated by the jackknifing approach (Zahl, 1977) taking into account all the samples collected. Bray-Curtis dissimilarity index was used to compare cladocerans + copepods from open water versus among plants + shore, using the square root transformation of the average proportion of these crustaceans in each habitat for each sampling date. The index of fluctuations formulated by Dubois (1973) as Taylor's expansion of Shannon diversity index around a reference state $D_{0}=\sum p_{i} \log _{2}\left(p_{i} / P_{i}\right),\left(p_{i}=\right.$ proportions of species $i$ and $P_{i}=$ mean of $p_{i}$ ) was also calculated as a measure of stability (Miracle, 1978), using rotifer + crustacean proportions from quantitative and $45 \mu \mathrm{m}$ net samples. $K$ index was calculated according to Margalef (1997) as $K=\log S / \log N(S=$ species number, $N=$ total density or total biomass from quantitative samples).

\section{RESULTS}

\section{Environmental characteristics}

In general, limnological features responded to water-level fluctuations determined by rainfall, although the variation in pond level is subject to inertia, because it is regulated by the perched, superficial "raña" aquifer. The duration of hydroperiods differed in the studied years (Fig. 1). In the first year, a long hydroperiod involving rainfall in autumn and spring was observed; in the second year the pond was dry in late autumnearly winter. After filling to a moderate level in autumn 2006, the pond was maintained through winter-early spring 2007 until the important precipitations of April increased its water volume, attaining a level that surpassed the average yearly limits, thus flooding the agricultural fields adjacent to the pond basin. High evapotranspiration values in summer and very low rainfall after late spring prevented the hydroperiod from lasting beyond early July. Rainfall in September filled a few very small puddles in the deepest part of the 

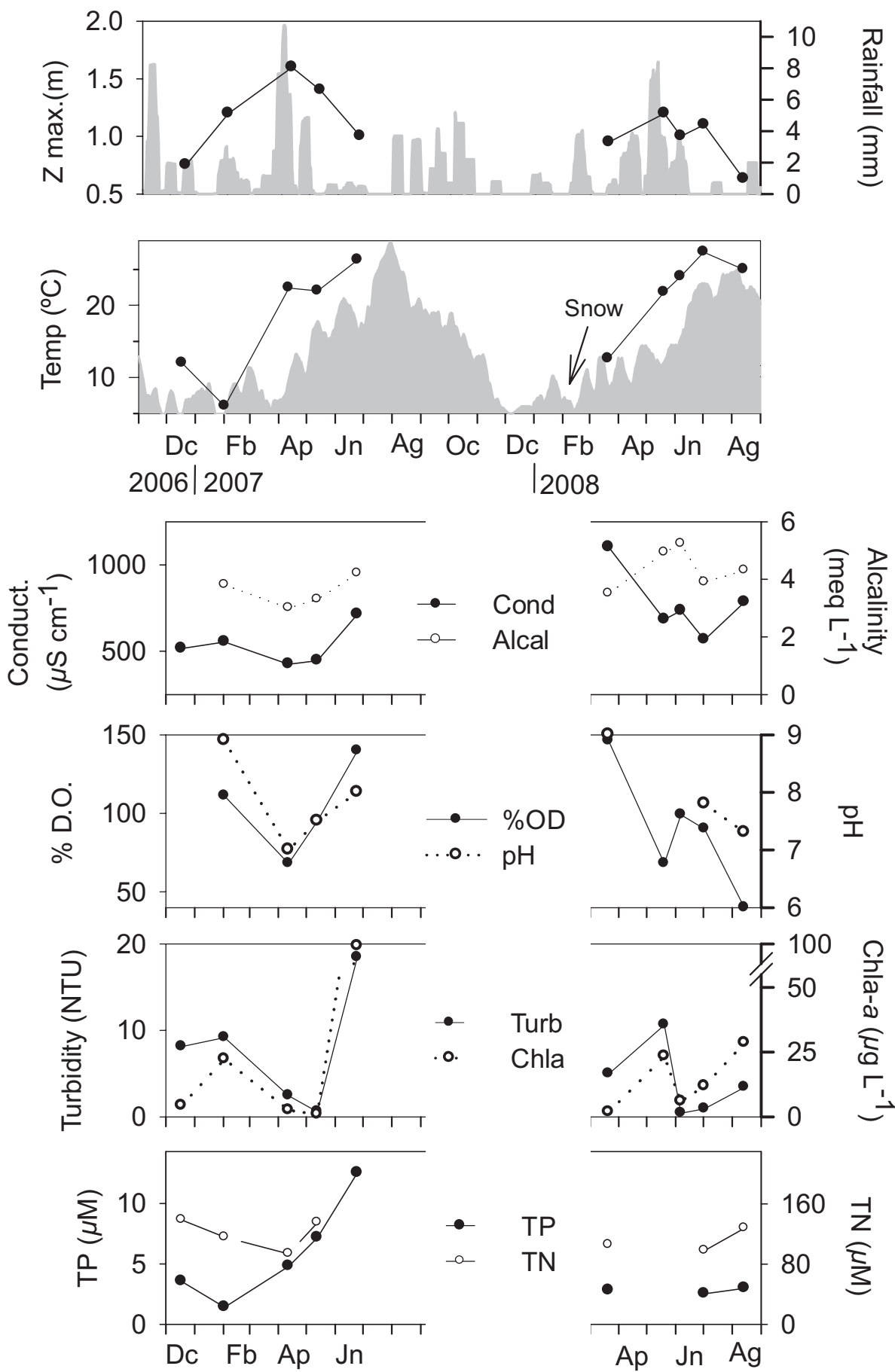

Figure 1. Rainfall and air temperature in the village of Sinarcas (grey areas; smoothed daily data 2006-08). Limnological features in Lavajo de Abajo de Sinarcas during two hydroperiods in 2006-07 and 2008: maximum depth (Z máx), and water temperature (black circle and solid line) conductivity and alkalinity dissolved oxygen and $\mathrm{pH}$, turbidity and planktonic chlorophyll- $a$ and total phosphorous and total nitrogen. Precipitación y temperatura en el pueblo de Sinarcas (áreas grises; datos diarios suavizados 2006 08).Características limnológicas en el Lavajo de Abajo de Sinarcas durante los hidroperiodos de 2006-07 y 2008: profundidad máxima ( $\mathrm{Z}$ max), y temperatura del agua (círculo negro y línea sólida) conductividad y alcalinidad, oxígeno disuelto y pH, turbidez y clorofila-a planctónica y fósforo total y nitrógeno total. 
basin with no more than $10 \mathrm{~cm}$ of water. Autumnal precipitation was very low in 2007 and, after a shallow water cover of short duration, the pond became dry in late autumn-early winter, but refilled in February 2008. Again, abundant precipitation in May increased the water level, flooding the adjacent agricultural fields and the hydroperiod lasted until the end of August.

The maximum depth and area clearly corresponded with spring rainfall peaks, (April 2007 and May 2008, Fig. 1). Water temperature on the sampling dates varied from $+5^{\circ} \mathrm{C}$ in winter to $+28^{\circ} \mathrm{C}$ in summer. Conductivity has increased in recent times since the use of salt for deicing the nearby road, peaking in the winters with snow, as in 2008, when it reached $1106 \mu \mathrm{S} \mathrm{cm}^{-1}$, whereas conductivity measured in May 1988 was $80 \mu \mathrm{S} \mathrm{cm}^{-1}$. In figure 1 , it can be observed that conductivity was lower during winter 2007 without snow and remained lower during that year. In both hydroperiods, severe evaporation in summer increased conductivity before desiccation, but never reached the winter values, when salt was used in the road. Alkalinity is high for the type of geological substrate but it probably has increased due to agricultural practices, since it is much higher than in the nearby artificially deepened permanent pond. Turbidity was higher in winter after filling and also in periods of less water. Water chlorophyll- $a$, turbidity and TP diminished in spring due to the important filtering of zooplankton biomass and nutrient intake by macrophyte development, a clear water phase in this period was very apparent. Later, these variables increased sharply at the end of the first hydroperiod studied, but not so clearly in the second period. Oxygen levels measured around midday varied between $68 \%$ and $138 \%$ saturation resulting in a corresponding variation in $\mathrm{pH}$ of 7 to 9 , with maxima at the beginning and the end of the hydroperiods, when primary production is higher. Oxygen undersaturation was observed just after spring rains (April 07, May 08) that may be attributed to replenishment of the pond in part through groundwater flow, mixing the water column with the poorly oxygenated bottom waters.

A visual follow up was made of the aquatic vegetation development on the different sampling dates. In late winter only young stems of Juncus and Eleocharis developed in the water, most of the pond consisting of open waters with a more or less heavy development of filamentous metaphyton depending on the years, in part due to fertilization (mainly nitrogenous) of the adjacent agricultural fields in late winter. The metaphyton was especially dense at the beginning of the 2008 hydroperiod (March), the year with low rainfall in autumn-winter; it covered the whole pond as a filamentous mat and slimy masses of these green algae accumulated on the shore and plant stems. The aquatic vegetation began to grow conspicuously at the beginning of spring, to form two different rings - when well developed: a Ranunculus dominated shallower outermost ring and a Myriophyllum dominated ring in the deeper more central part. At the end of the hydroperiod almost no open water could be seen. Anuran larvae were commonly present and larvae of the newt Pleurodeles waltl were observed in spring.

\section{Crustacean and rotifer succession}

A total of 12 cladocerans, 9 copepods (3 calanoids, 5 cyclopoids, and 1 harpacticoid), 1 concostracan, 1 notostracan, 2 anostracans and 36 rotiferans were collected and identified in the active community. The majority of these species are strictly linked to temporary waters.

Population dynamics of main species during the two hydroperiods of consecutive years are shown in figure 2 (from plankton quantitative samples) and figure 3 (from net samples among macrophytes). Three main phases can be distinguished:

\section{(1) Calanoid phase in late autumn-winter}

Best observed in the longer hydroperiod of 200607 . The pond filled by autumn-winter rainfall, had shallow waters with very sparse vegetation. A planktonic community of large-sized organisms dominated (characterized by the coexistence of anostraca and three diaptomids of different sizes). The endemic Branchipus cortesi was the main anostraca species, but Branchipus schaefferi could coexist at low numbers. Both species showed a percentage of individuals with the ab- 
normal rostrum/antenna morphotype, that some authors consider typical of Branchipus visnayi; however, it seems to be just a morphology that some specimens undertake as a response to fixatives (Beladjal \& Mertens, 1999; Miracle et al., 2008). At the very beginning of the hydroperiod in autumn, when water is still warm, Triops cancriformis can also be found in the littoral peripheral zone. The most characteristic diaptomids are two univoltine species Hemidiaptomus ingens inermis, Kiefer (4 mm), recorded for the first time in the Iberian Peninsula, and Diaptomus cya-

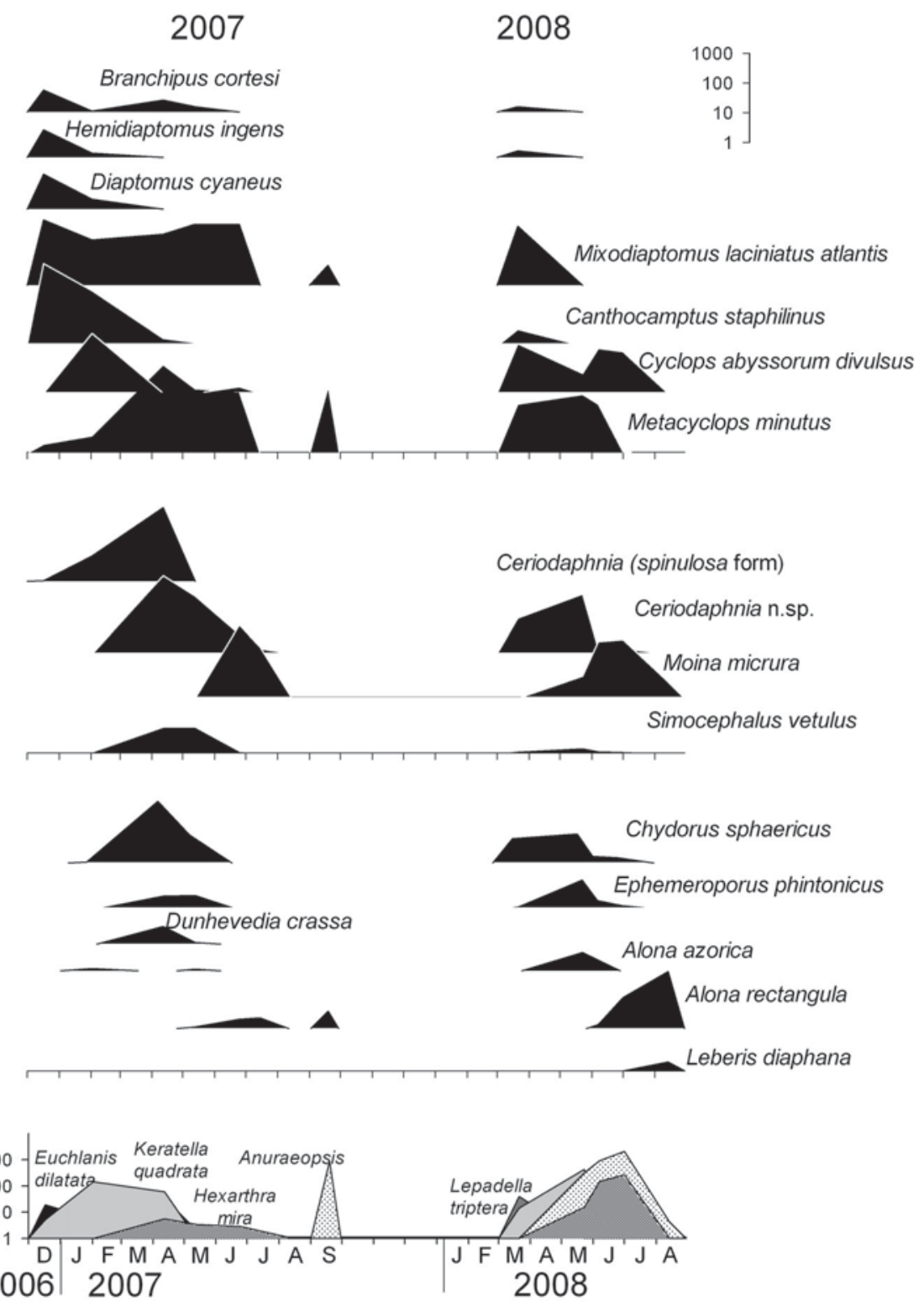

Figure 2. Population dynamics of main crustacean and rotifer species in Lavajo de Abajo of Sinarcas from quantitative plankton samples taken during the two main wet phases. Densities in ind $\mathrm{L}^{-1}$ are the averages of two sampling points. Dinámica de las poblaciones de las principales especies de crustáceos y rotíferos en el Lavajo de Abajo de Sinarcas en las muestras cuantitativas de plancton tomadas durante las dos fases húmedas principales. La densidad en ind $L^{-1}$ corresponde al promedio de los resultados de dos puntos de muestreo. 
neus intermedius, Aguesse \& Dussart (2 mm). They are the earliest colonizers, initial samples collected more or less two months after first filling (a shorter time in the second year) were made up of adults with absence of nauplia and copepodites, this denotes that egg hatching follows a desiccation period and happens more or less at once and also that resting eggs are concentrated in the deepest central zone of the pond. The third diaptomid species Mixodiaptomus laciniatus atlantis $(1.2 \mathrm{~mm})$ hatched a little later and had more than one annual generation. Early in this phase a benthic harpacticoid Canthocamptus staphilinus was very abundant, probably peaking before calanoids development. Cyclopoids $\mathrm{Me}$ tacyclops minutus and Cyclops abyssorum divulsus were present since early filling. Rotifers had a very low contribution to biomass, Keratella quadrata was the main planktonic species, but even in the plankton samples periphytic species were also found, the most abundant ones were Euchlanis dilatata at the beginning and Lepadella triptera at the end of the period.

The duration of this phase in this pond, marked mainly by the occurrence of $H$. ingens inermis, is approximately from December to March, and corresponds with maximum air temperatures below $+15^{\circ} \mathrm{C}$. In the quantitative samples, collected diaptomids contributed up to 79 and $90 \%$ (February 2007 and March 2008 respectively) of the zooplankton biomass, and $H$. ingens inermis alone contributed up to $38 \%$.

\section{(2) Cladoceran phase in spring}

Water changes from turbid to transparent and consumers predominate in the water. The pond had a well developed macrophyte cover and tadpoles and insect larvae were abundant. Benthic, littoral and/or phytophyllic taxa dwelled together with planktonic taxa. In the planktonic community Ceriodaphnia n. sp. and anostraca (Branchipus species) dominated. Ceriodaphnia n. sp. presented a succession of two morphs, a spinulosa form, characterized by very heavy reticulations that from a lateral view look like small spines, appeared earlier. But its dominance was soon replaced by a smaller form of this Ceriodaphnia with smooth reticulations. This Ceriodaphnia is similar to C. quadrangula as described by Alonso (1996), but according to this author and to D. Berner (personal communication) it rather corresponds to a new species which are now describing, the main difference being that the new species has a cervical fenestra, which is not found in C. quadrangula s.s. Planktonic cladocerans coexisted with a rich association of periphytic cladocerans, composed of at least five different species of good swimmer chydorids (i.e. Ephemeroporus, Chydorus) and Simocephalus vetulus, also Alona azorica had a maximum in this period. Amphigonic reproduction, also registered in figure 3 indicated clearly the species replacements, with the first to come being the planktonic Ceriodaphnia species, followed by periphytic cladocerans (Simocephalus, Dunhevedia and Ephemeroporus) and later by the more benthic Alona azorica. In the littoral benthos two large branchiopods were found Maghrebestheria maroccana and T. cancriformis. Metacyclops minutus was the most abundant copepod. Univoltine calanoids had completely disappeared, but the multivoltine $M$. laciniatus atlantis was still abundant. Dominant planktonic rotifers differ from year to year and a variety of periphytic rotifers began to develop (including uncommon predaceous species such as Cupelopagis vorax and Asplachnopus multiceps).

In Lavajo de Sinarcas this phase is observed since early spring (end of March) until mid June, more or less, and corresponds with maximum air temperatures below $+25^{\circ} \mathrm{C}$. Although the phase duration is shorter than the first phase, the number of species is higher.

\section{(3) Desiccation phase}

As the hot summer is approaching, the level of the pond diminishes, but the length of this phase depends on the intensity and timing of spring rainfall. Large branchiopods had disappeared before the start of this phase. In these warm waters, planktonic crustaceans are characterized by the almost absolute dominance of Moina micru$r a$ with a small proportion of cyclopoids, mainly the predator C. abyssorum divulsus but M. minu- 


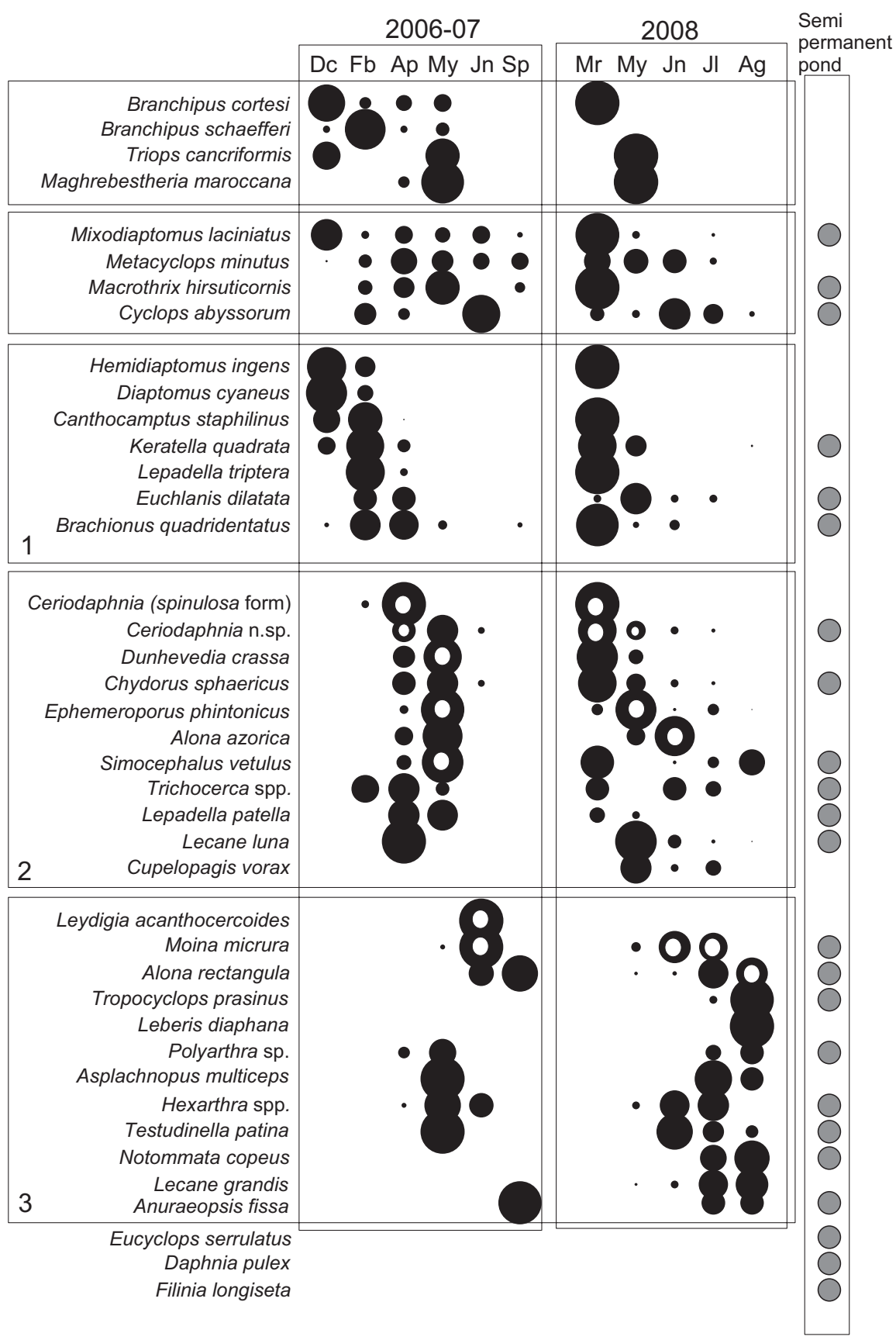

Figure 3. Summary of seasonal succession of crustaceans and rotiferans found in Lavajo de Abajo of Sinarcas from sweep net samples among macrophytes during two hydroperiods, 2006-07 and 2008. Circles indicate the relative abundance of each species in each sampling day with respect to the total number of individuals of this species over each wet phase. White circles indicate the presence of ephippial females. Number on the left side refers to seasonal groups of species (1 to 3, see text). On the right side, grey circles indicate species presence in a nearby simultaneously sampled pond, Lavajo de Arriba of Sinarcas (artificially converted in a semi-permanent pond). Sucesión estacional de crustáceos y rotíferos en el Lavajo de Abajo de Sinarcas en muestras con red de mano entre macrófitos durante dos hidroperiodos, 2006-07 y 2008. Los círculos indican la abundancia relativa de cada especie en cada día de muestreo respecto del total de individuos de esta especie en cada fase húmeda. Los círculos blancos indican la presencia de hembras efipiales. A la izquierda se señala con un número los correspondientes grupo estacionales de especies ( 1 a 3 , ver texto). A la derecha, en círculos grises, se señala la presencia de las especies en muestras tomadas simultáneamente en una charca cercana, Lavajo de arriba de Sinarcas (artificialmente transformada en semi-permanente). 
tus was also present. In the year with a longer hydroperiod some adults of M. laciniatus atlantis still remained. Depending on the year, rotifers may be more or less abundant, mainly comprising the more detritivorous Hexarthra mira and Trichocerca spp. Phytophylous cladocerans were now less abundant being replaced by benthic ones, such as Alona rectangula and Leydigia acanthocercoides. In this case also the planktonic species $M$. micrura showed an earlier amphigonic reproduction than $A$. rectangula.

In the second studied period (2008) later rainfall in spring prolonged the hydroperiod until August. In this month the pond was practically covered by the structural parts of vegetation stands in different rings, leaving only a small central aperture. Invertebrate predators were mainly Chaoborus in the central open water and heteropterans in the shores. Diversity drastically diminished, but density was high in the small water volume. The benthic cladoceran $A$. rectangula dominated altogether with periphytic rotifers. Phytophylous cladocerans were very scarce. The occurrence of Leberis diaphana $(0.6 \mathrm{~mm})$ was remarkable; it was recorded for first time during that exceptional summer, as was the presence of several predatory rotifers, such as Notommata and Asplachnopus multiceps (an individual of the latter had four Chydorus sphaericus inside). However, at the same time, plankton was dominated by opportunistic species, newcomers that are not characteristic of temporary ponds, such as the cyclopoid Tropocyclops prasinus.

In the two study years the pond differed in water level, extension and hydroperiod length. In the first more humid year the pond had a high level of water from autumn until early summer, whereas in the second year the pond was dry in late autumn - early winter and it was filled in late winter, but then due to late spring rains the hydroperiod lasted until midsummer. In this second year, winter species were much less abundant and had to cope with the prompt development of spring species; calanoids and anostracans were much less abundant and much less persistent, even the more numerous and enduring $M$. laciniatus atlantis was scarce and finished its active cycle long before. Furthermore, during the second year, rotifers presented a higher relative abundance and a higher number of periphytic species (mainly Lecanidae) than in the previous year.

As a comparison, figure 3 indicates the species found in the nearby, simultaneously sampled, "Lavajo de Arriba de Sinarcas", converted into a semipermanent pond by man digging (presence of species in any of the sampling dates). This pond did not dry during the study period and species richness was less than half that found in the temporary pond, 11 crustacean species were found, all of them widely distributed.

\section{Dynamics of diversity}

Diversity index and species richness showed marked seasonal and inter-annual variations according to the above-mentioned changes in community composition (Fig. 4). The pronounced slope of accumulated species richness indicates high community change. The number of species was more or less equal in both years but the second year was richer in rotifer species. Shannon diversity index, $H^{\prime}$ applied to crustacean proportions differed seasonally (ANOVA $p<0.01$, applied to 2007 and 2008 samples separately). The minimum $H^{\prime}$ values were found in the samples corresponding to changing conditions: (1) just after flooding and (2) at the beginning of desiccation. $H^{\prime}$ increased with time after the pond was replenished and reached maximum values in spring, with a more stable environment of high water level, warm temperatures and high development of aquatic plants, providing refuge and feeding resources. Then, it decreased in summer when hot temperatures and dryness reduced water level. From the multiple samples taken each day, the overall values of the diversity indices were calculated by the jackknifing procedure to obtain less biased estimates with a confidence interval (Fig. 4). The general trend of this estimator through time was the same as that previously described for single samples, with a maximum in spring. The jackknife estimator compensates the underestimation associated with sampling size but also reflects habitat heterogeneity, as the difference between mean sample diversity and jackknife estimator. There is a correspondence 


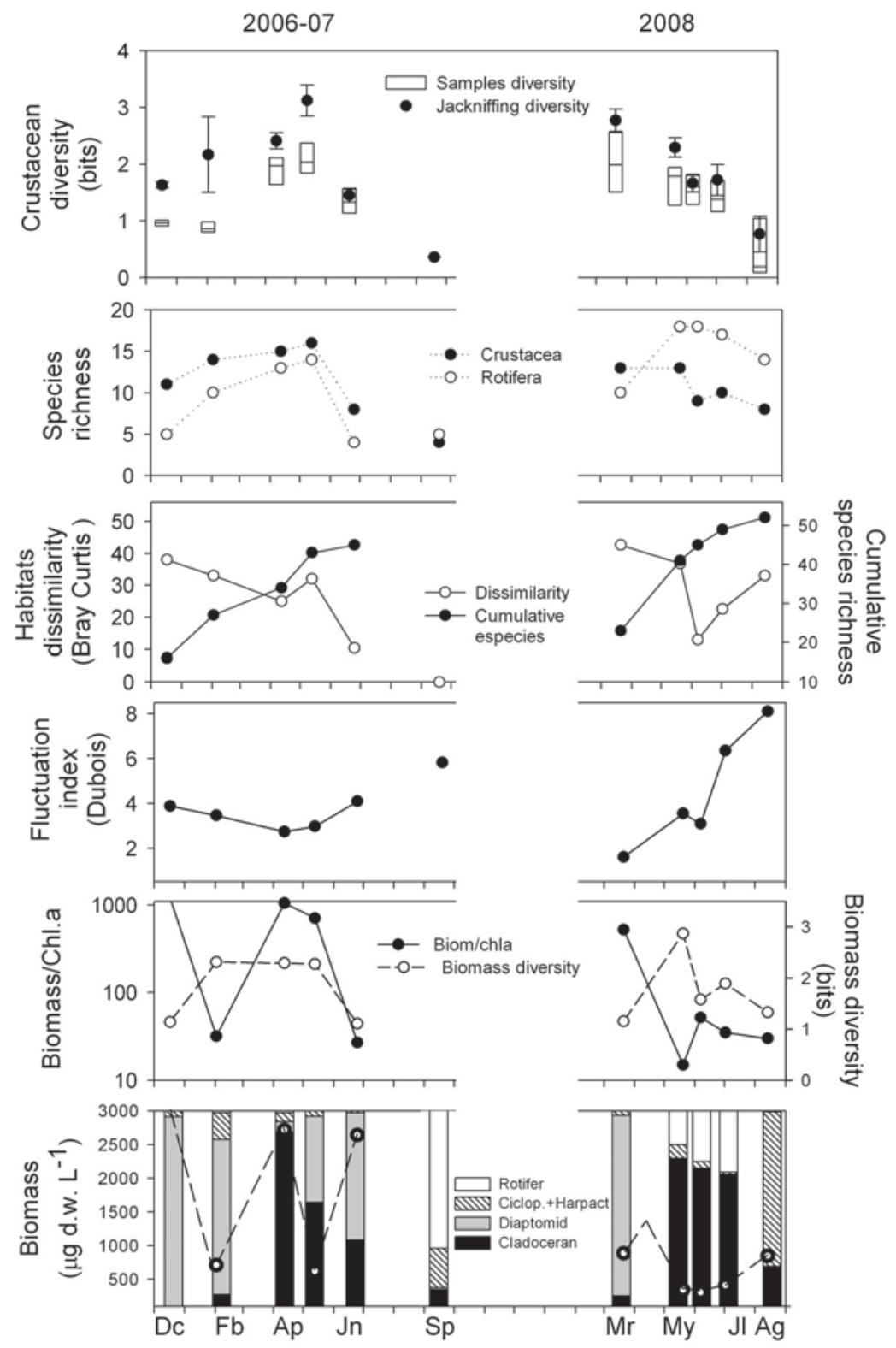

Figure 4. Dynamics of different parameters during the two hydroperiods studied in Lavajo de Abajo of Sinarcas: Crustacean (cladoceran + copepods) sample diversity (Boxplot boundaries indicate the 25 and the 75th percentiles, a line within the box marks the median), and Jackknifing estimator of crustacean diversity with its standard deviation. Species richness of crustaceans + rotifers calculated over all the samples collected every sampling date. Cumulative species richness of crustaceans + rotifers and Bray Curtis crustacean dissimilarity between habitats: open water and among macrophytes. Dubois fluctuation index calculated around a reference state (see methods) for crustaceans + rotifers. Ratio of crustaceans + rotifers biomass/chlorophyll- $a$ and diversity $\left(H^{\prime}\right.$, for biomass of crustaceans + rotifers). Total crustaceans + rotifers biomass, mean (filled circles) and relative contribution of different groups to total biomass (stacked bars). Dinámica de diferentes parámetros durante los dos hidroperiodos estudiados en el Lavajo de Abajo de Sinarcas: Diversidad de las muestras de crustáceos (cladóceros + copépodos, los límites de las cajas indican los percentiles 25 y 75, la línea dentro de la caja señala la mediana), y estimador "Jackknifing” de la diversidad con su desviación estándar. Riqueza de especies de crustáceos y rotíferos calculado sobre todas las muestras recogidas durante cada fecha de muestreo. Riqueza acumulada de especies de crustáceos + rotíferos e índice de disimilaridad de Bray Curtis entre los crustáceos en aguas abiertas y en macrófitos. Índice de fluctuación de Dubois calculado en torno a un estado de referencia (ver métodos) para los rotíferos + crustáceos. Relación entre la biomasa de rotíferos + crustáceos y la clorofila-a, y diversidad de la biomasa de rotíferos + crustáceos $\left(\mathrm{H}^{\prime}\right)$. Biomasa total de rotíferos+ crustáceos: valor medio (círculos negros) y contribución relativa de los diferentes grupos (barras acumuladas). 
between these differences and habitat heterogeneity, estimated as the Bray-Curtis dissimilarity coefficient between samples from the open waters and from the littoral + among plants. Dissimilarity was important in winter when the pond had scarce aquatic vegetation; however, wind promotes not only the mixing of waters but also a non-homogenous distribution of planktonic organisms, giving rise to a coarse-grain distribution, which was reflected in our samples. Spring rainfall homogenized and a low dissimilarity was observed just after the rains (April 2007 and May 2008). With time, plant development stabilized the water column and promoted a fine-grain habitat diversification and the community recovered habitat heterogeneity, so dissimilarity increased (as in June 2007). Later summer desiccation proved a powerful de-structuring force that reduced diversity and heterogeneity (as in August 2008).

The Dubois fluctuation index indicates the stability of the community. Higher values indicate the periods when the community is far from the reference state defined as the average species proportion over the whole study period. In our samples the periods with strongest deviations were associated with initial flooding and especially with the end of the hydroperiods corresponding to extreme conditions due to desiccation (high temperatures, intensive predation, and reduced water volume).

Density of microcrustaceans and rotifers did not differ greatly between the two years, but maximum biomass achieved was much greater the first year. The main reason was the higher relative contribution of calanoids during the first year and the higher contribution of rotifers during the second year (Fig. 4), although rotifers were always much less important than crustaceans. It is clear that the system in the longer hydroperiod can attain a higher biomass with larger organisms. The shorter period favours a community of smallersized organisms than can develop further, but the arrival and growth of opportunistic species is also easier when changes occur. The ratio zooplankton/chlorophyll is higher in the first phase and then diminishes just after re-filling events before increasing afterwards. It should vary with diversity but in the shorter 2008 hydroperiod due to merging of the first and second phases, diversity was anomalously higher in May after flooding.

The community dynamics change (Fig. 5), expressed as the relationship between density or biomass and the number of species, which was proposed by Margalef (1997), is a good approach to compare these year cycles. After winter flooding there is a large increase in the density or biomass with low diversity, then productivity declines and diversity increases. Later an increase in light and temperature, as well as rainfall, may en-
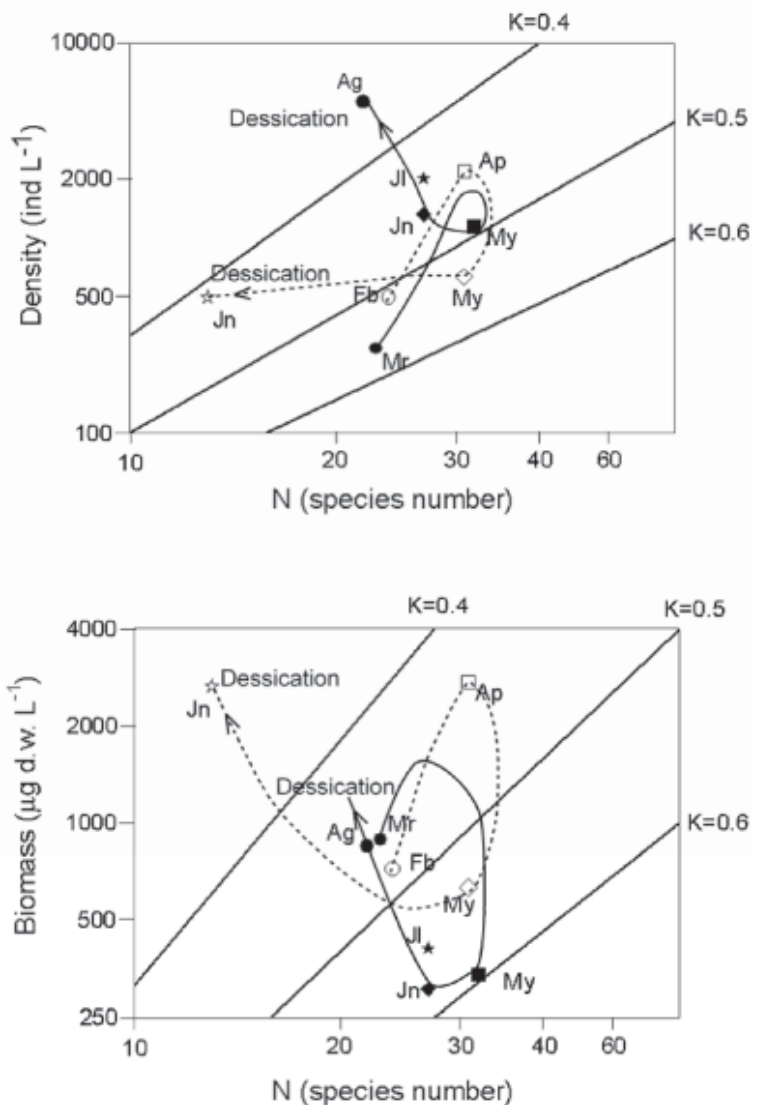

Figure 5. Idealized trajectory of the community structure during the two wet cycles 2007 (solid points and line) and 2008 (dashed line and empty points). Points are the monthly means of rotifer+crustacean species number in relation to their densities or biomass during the two wet cycles. $K=\log$ species number $/ \log$ density $K^{\prime}=\log$ species number/log biomass. Trayectoria idealizada de la estructura de la comunidad durante los dos ciclos húmedos estudiados, 2007 (línea continua y puntos sólidos) y 2008 (línea discontinua y puntos vacíos). Los puntos representan la media mensual del número de especies de crustáceos y rotíferos en realción con su densidad o biomasa en los dos ciclos húmedos. $\mathrm{K}=\log n^{o}$ de especies/log densidad, $\mathrm{K}^{\prime}$ $=\log n^{o}$ de especies/log biomasa. 
hance productivity with a new increase in density or biomass and diversity drops slightly, but immediately increases again due to the rich sediment seed bank. Then, the desiccation process decreases diversity and the biomass of characteristic species, but can increase opportunistic species biomass.

\section{DISCUSSION}

\section{General pattern of community succession with three phases}

In Lavajo de Abajo de Sinarcas, two characteristics could be identified; firstly the singularity of its aquatic fauna and secondly, the clear successional phases made up by the replacement of different taxonomic communities. Although a general seasonal pattern of species associations can be observed, there are some variations depending on the timing of rainfall and the duration of the hydroperiod. Lavajo de Abajo may vary from several discontinuous pond events of a few months to a continuous flooding period that can even cover part of the summer season. The first hydroperiod studied had an adequate duration (8 months) and timing of occurrence (from autumn 2006 to summer 2007) for a clear observation of the development of the successional phases.

The first water filling involves an input of energy to the system; the dissolution of nutrients induces the growth of planktonic primary producers and subsequently of planktonic filter feeders, which present a clear variation in body sizes that allows the consumption of food of a wide range of particles avoiding competition. The temporary ponds of the Mediterranean basin filled typically after autumnal rainfall (in July in the southern hemisphere), corresponding with the coolest months of the year and short photoperiod. In "Lavajo de Abajo de Sinarcas" this earlier phase at the end of autumn-winter is the most peculiar and it is characterized by anostraca and three calanoid species (two of them are large univoltine species with long life spans) representing a very specialized community well adapted to this period and exclusive from it, that takes advantage of the initial planktonic conditions. Com- parative studies on temporary ponds from localities with large differences in climate and zoogeography have shown that considerable similarity is evident amongst the seasonal cycle of invertebrates (Williams, 1997). An initial colonization after flooding by co-occurring calanoids of different sizes has also been described in many locations where annual cycles have been followed (i.g. Champeau, 1971, in Europe; Lake et al., 1989, in Australia with 4 co-occurring species of calanoids; Taylor \& Mahoney, 1990, in South Carolina ,USA). Moreover, in these cases, as in Lavajo de Abajo of Sinarcas, this phase is also followed by a spring community dominated by cladocerans. This cladoceran phase was called the middle phase by Lake et al. (1989). Taylor \& Mahoney (1990) hypothesized that later emergence of cladocerans is related to food resources and temperature conditions. Food is low when ponds fill in winter and newly hatched cladocerans must begin to feed immediately (Goulden \& Henry, 1984), differing from newly hatched copepods and anostraca larva that could relay on egg reserves.

In this middle phase, another input of energy, now from spring rainfall, give rises again to a higher biomass and then succession progressively advances. A "clear water phase", as described in permanent lakes (Sommer et al., 1986) appears as a consequence of zooplankton increase but, in this shallow pond also due to the expected reduction of turbidity by macrophytes. The zooplankton community is dominated by cladocerans, although many of them are species associated with plants. The middle phase length may be shorter than the first phase but the number of species is higher and diversity reaches its maximum. Main attributes of succession may be followed in this middle phase, such as a decline of the ratio production/biomass, an increase of the ratio zooplankton/chlorophyll and an increase of diversity, although they fluctuate with perturbations due to re-filling events after heavy spring precipitations. Succession proceeds with a switch to dominance of larger and more complex organisms, macrophytes and insects and diversity of crustaceans and rotifers may diminish. This complex autoorganization and high biotic interactions has led to define this phase as an autogenic phase by so- 
me authors (Lake et al., 1989; Boix et al., 2004) to indicate that, in great part, it is the result of autogenic biological processes in the pond to differentiate from the flooding and desiccation phases that are considered to have a high influence of allochtonous factors.

The desiccation phase occurs in summer and is characterized by a strong reduction of species richness and the occurrence of more ubiquitous species at the end of this phase. As in other places (Crosetti \& Margaritora, 1987), the main planktonic species is Moina micrura that appeared when other cladocerans diminished. Community changes are abrupt; the stressful conditions during the drying process decrease species richness, however subsequent die-back of aquatic plants and emergence of aerial insects, as well as confinement and reduced volume of water will produce again a rise in density or biomass of microcrustaceans and rotifers. But the directionality of density or biomass of microinvertebrates could be variable depending on the presence of numerous young stages of species in rapid development or many individuals of small species as rotiferans. As in other studies, there is an increase of invertebrate predators (Lake et al., 1989) in the centre of this phase. If this phase is prolonged some ubiquitous species such as the cyclopoid $T$. prasinus can colonize the pond. In "Lavajo de Abajo" we attribute the presence of T. prasinus in August to dispersion by sheep or other means from the nearby artificially permanent pond.

\section{Interannual variability}

In this fluctuating environment, the seasonal cycle of the active community may show a high interannual variability of its structure, although main elements are present. According to Margalef (1997) the relationship between number of species and number of individuals (or biomass) is a good approach to look for structural or diversity changes in the community. In figure 5, idealized trajectories of the structure of crustacean-rotifer community in the seasonal cycle, based on available monthly averages, seemed to indicate that the cycle begins with a relatively high richness of species and that in both years a similar maximum value of species richness was attained in May. However in the wetter year, with a long lasting hydroperiod beginning in autumn, crustacean dominance was the rule and a higher biomass was reached during colonizing and desiccation phases than in the dryer year and a higher biomass was maintained as well during the middle phase. On the other hand, in the later stages of this wetter year, densities were much lower to those of the dryer year, indicating that biomass consisted of larger animals with lower rates of growth. Whereas in the dryer year, with shorter interrupted hydroperiod, the main one beginning in March, rotifers were more diverse and more abundant than in the wetter year, although crustaceans contributed also to biomass in greater proportion (Fig. 4). In the dryer year, the first phase was the most affected, giving rise to a phase at the end of winter characterized by the fusion of the two first phases, microcrustaceans of the two phases autumnwinter and spring had to coexist, in detriment of the early colonizers. In this dryer year the least frequent species among calanoids as well as the rarer cladoceran species or forms were less abundant or not found. Moreover, in this dryer year, the lower development of copepods and anostracans favoured rotifers that increased the number of species per sample, but also influenced the accumulated number of species due to the higher seasonality of this short lived group of organisms (Fig. 4).

\section{Phenology and sediment bank}

Production of resting stages and the timing of hatching from them determines the dynamics of the active populations (Champeau, 1971, Crosseti \& Margaritora, 1987), subsequently mechanisms such as food limitation and predation influence also the densities of the different species.

The phenology of faunal elements is the main cue determining the seasonal phases, diapause and hatching adaptations regulated by temperature and photoperiod, among other factors, in branchiopods and copepods are the main determinants of replacement patterns. Crosetti and Margaritora (1987) pointed out that despite differences in duration of hydroperiods, cladocerans followed similar cycles, indicating the ma- 
jor role of temperature and photoperiod in the life cycle. The same is true in "Lavajo de Abajo" where cladocerans showed successive amphigonic reproductions according to their appearance. Champeau (1971) also described how diapause eggs of winter diaptomids need a dry summer period with high temperatures and then the autumnal cooling for hatching. In summary, different changing conditions trigger egg hatchings of branchiopods and calanoids or activate diapausing stages of cyclopoids or harpacticoids, and their populations develop in pulses following the environmental cue.

When a succession begins in the new wet habitat after drying, fast growing and opportunistic species would be expected to develop earlier, but in this temporary pond the strategies adapted by the earlier community after first flooding when it occurs in winter, is dominated by low growth and large species, especially calanoids adapted to interannual persistence, in detriment of high growth in a particular year, probably bet-hedgers strategist to maximize geometric mean fitness (DeWitt \& Lagerhans 2004). This suggests that a larger temporal scale is important; apart from a habitat that begins at each hydroperiod and can be analysed in a short time scale, there is a predictable cycle shaped by a stable community that becomes seasonally activated.

\section{Singular and rich community of an ancient temporary pond}

From a regional point of view many of the species found in Lavajo de Sinarcas have an exclusive occurrence in this pond. Within the species recorded we have found one Iberian endemic anostracan, Branchipus cortesi, and the conchostracan Maghrebestheria maroccana, both species are very rare and formerly believed to be restricted to the western part of the Iberian Peninsula (Alonso \& Jaume, 1991; Pérez-Bote, 2004). Their presence in Lavajo de Abajo of Sinarcas indicates that the distribution of these species is wider, since Sinarcas is in the Eastern border of the Peninsula high plateau, and that it may be more related to a relatively well preserved similar habitat than a too strict geographical po- sition. Other species have been recorded for the first time in the Iberian Peninsula such as $\mathrm{H}$. ingens inermis, $L$. diaphana and a spinulated form of Ceriodaphnia n. sp. There are also uncommon species such as Ephemeroporus phintonicus and Alona azorica. In Lavajo of Sinarcas a combination of circum-Mediterranean fauna, steppic North-African species and species from southern European mountains co-occur. The multispecies occurrence of large branchiopods and calanoids in this pond is remarkable, since single occurrences within these groups of organisms is the most common situation. However, the association of calanoid species of different sizes in the Mediterranean basin has been noted by different authors in well structured ponds (Gauthier, 1928, Champeau, 1971, Miracle, 1982, Alonso, 1987, Marrone \& Naselli-Flores, 2004). The endemic character and uncommonness of several of the species suggests that this is a well established community of biogeographical and historical interest. In fact, this fauna still persists in this typical "raña" pond whose relatively soft waters have been recently altered, increasing its alkalinity and chloride contents due to expanding agricultural activities and road de-icing practices, respectively. The outermost part of peripheral zones of this temporary pond have been converted into a cereal field and a vineyard, that are flooded every spring, this is highly risky for the rare large littoral/benthic branchiopods whose resting eggs were observed in the peripheral zones, such as M. maroccana and T. cancriformis (Miracle et al., 2008).

This dynamic point of view about community richness in temporary ponds implies that the maintaining of its natural cycles is a main target for conservation. The natural succession is internally fed by the rich dormant community stored in the egg bank (Brendonck \& De Meester, 2003) and then the well structured community maintains some inertia to new opportunistic colonizers. On the other hand, the manipulation of the physical characteristics of the pond results in an increase of opportunistic species as it occurs in the excavated nearby semi-permanent pond. In summary, conversion of peripheral flooding lands in agricultural fields, fertilization and pesticide treatments in this and adjacent fields, use of salt 
on the road and pond improvement schemes for water permanence are seen as alarming threads towards the survival of "Lavajo de Abajo de Sinarcas". Accordingly, this pond should be identified as a priceless site for conservation of a biodiversity hot spot and an ancient natural type of temporary pond ecosystem. All land that is susceptible to flooding in the pond basin should not be considered as wasteland nor as land that needs restoration, instead it should be conserved and protected from the above mentioned threats by removing human activities from it, even if does not fill in several years. Furthermore it is also necessary to regulate those activities that could have an impact upon its watershed.

\section{ACKNOWLEDGEMENTS}

We are very grateful to Eduardo Vicente for his help in the field and laboratory work, and also to Sara Morata and Antonio Picazo for the help in chemical analyses. We thank also I. Lacomba and V. Sancho for assistance in the field and Coop.V.V. 'La Protectora' in Sinarcas for meteorological data. This research has been supported by the EC project LIFE05/NAT/E/000060.

\section{REFERENCES}

ALONSO, M. 1998. Las lagunas de la España peninsular. Limnetica, 15: 1-176.

ALONSO, M. 1996. Crustacea Branchiopoda. Fauna Ibérica 7. Museo Nacional de Ciencias Naturales, Madrid. 486 pp.

ALONSO, M. \& D.JAUME. 1991. Branchipus cortesi n. sp.: a new anostracan from western Spain (Crustacea, Branchiopoda). Hydrobiologia, 212: 221-230.

[APHA] AMERICAN PUBLIC HEALTH ASSOCIATION. 1992. Standard methods for the examination of the water and wastewater, 18th edition. Washington, D. C. 1008 pp.

BELADJAL, L. \& J. MERTENS. 1999. Direct preservation in alcohol causes deformation of taxonomic key-characters in Anostraca (Crustacea). Int. Rev. Hydrobiol., 84: 17-22.

BOIX, D., J. SALA, X. QUINTANA \& R. MORENO-AMICH. 2004. Succession of the animal community in a Mediterranean temporary pond. $J$. N. Am. Benthol. Soc., 23(1): 29-49

BOTTRELL, H. H., A. DUNCAN, Z. M. GLIWICZ, E. GRYGIEREK, A. HERZIG, A. HILLBRICHTILKOSKA, H. KUROSAWA, P. LARSON \& T. WEGLENSKA. 1976. A review of some problems in zooplankton production studies. Norw. J. Zool., 24: 419-456.

BRENDONCK, L. \& L. DE MEESTER. 2003. Egg banks in freshwater zooplankton : Evolutionary and ecological archives in the sediment. Hydrobiologia, 491: 65-84.

CÉRÉGHINO, R., J. BIGGS, B. OERTLI \& S. DECLERCK. 2008. The ecology of European ponds: defining the characteristics of a neglected freshwater habitat. Hydrobiologia, 597: 1-6.

CHAMPEAU, A. 1971. Originalité du peuplement de Copépodes dans les eaux temporaires de BasseProvence et de Corse. Annales de l'Université de Provence, Science, 45: 55-80.

CROSETTI, D. \& F. G. MARGARITORA. 1987. Distribution and life cycles of cladocerans in temporary pools from Central Italy. Freshwat. Biol., 18: 165-175.

DEWITT, T. J. \& R. B. LAGERHANS. 2004. Integrated solutions to environmental heterogeny: Theory of multimoments reaction norms. In: Phenotypic plasticity: functional and conceptual approaches. T. J. Dewitt \& S. M. Scheiner (eds.): 98111. Oxford University Press US.

DUBOIS, D. M. 1973. An index of fluctuations, Do, connected with diversity and stability of ecosystems: applications in the Lotka-Volterra model and in an experimental distribution of species. In: Belgian National R-D Program on the environment. Sea project. Mathematical Model Annual report III: 320-345. é.t.a.b.é.t.y.p. Liège.

DUMONT, H. J., I. VAN DE VELDE \& S. DUMONT. 1975. The dry weight estimate of biomass in a selection of cladocera and rotifera from the plankton, periphyton and benthos of continental waters. Oecologia, 19: 75-97.

EBERT, T. A. \& M. L. BALKO. 1987. Temporary pools as islands in space and time: the biota of vernal pools in San Diego, Southern California, USA. Archiv für Hydrobiologie, 110: 101-123.

FAHD, K., M. FLORENCIO, C. KELLER \& L. SERRANO. 2007. The Effect of Sampling Scale on Zooplankton Community Assesment and Its Implication for the Conservation of Temporary Ponds in 
South-West Spain. Aquatic Conservation-Marine and Freshwater Ecosystems, 1-19.

FOS, S., C. PEÑA, A. SEBASTIAN \& V. I. DEL TORO. (2008). Redescubrimiento de Littorella uniflora (L.) Asch. en los lavajos de Sinarcas (Valencia). Flora Montiberica, 39: 46-49.

GAUTHIER, H. 1928.Recherches sur la faune des eaux continentales de l'Algérie et de la Tunisie, Imprimerie Minerva, Algeria. 425 pp.

GOULDEN, C. E. \& L. L. HENRY 1984. Lipid energy reserves and their role in cladocera. In: Trophic interactions within aquatic ecosystems. D. G. Meyers \& J. R. Strickler (eds.): 167-185. AAAS Selected Symposium, Ser. 85. Westview.

LAGUNA, E., V. DELTORO, S. FOS, P. PÉREZ ROVIRA, G. BALLESTER, A. OLIVARES, L. SERRA \& J. PÉREZ BOTELLA. 2003. Hábitats prioritarios de la Comunidad Valenciana: Valores faunísticos y botánicos. Conselleria de Medi Ambient, Aigua, Urbanisme i Habitatge. 222 pp.

LAHR, J., A. O. DIALLO, K. B. NDOUR, A. BADJI \& P. DIOUF. 1999. Phenology of invertebrates living in a sahelian temporary pond. Hydrobiologia, 405: 189-205.

LAKE, P. S., I. A. E. BAYLY \& W. MORTON. 1989. The phenology of a temporary pond in western Victoria, Australia, with special reference to invertebrate succession. Archiv. Hydrobiol., 115: 171202.

LATJA, R. \& K. SALONEN. 1978. Carbon analysis for the determination of individual biomasses of planktonic animals. Verh. Internat. Verein. Limnol., 20: 2556-2560.

LUOKKANEN, E. 1995. Vesikirppuyhteisön lajisto, biomassa ja tuotanto Vesijärven Enonselällä. Helsingin yliopiston Lahdentutkimus-ja koulutuskeskuksen raportteja ja selvityksiä, 25: 1-53.

MAHONEY, D. L., M. A. MORT \& B. E. TAYLOR. 1990. Species richness of calanoid copepods, cladocerans and other branchiopods in Carolina bay temporary ponds. The American Midland Naturalist, 123: 244-258.

MANSANET, J. \& G. MATEO.1978. Sobre la vegetación de la clase Isoeto-Nanojuncetea en la provincia de Valencia. Anal. Inst. Bot. A.J. Cav., 35: 219-223.

MATEO, G. 1983. Estudio sobre la flora y vegetación de las sierras de Mira y Talayuelas. Monografia 31. ICONA. Madrid. 290 pp.
MARGALEF, R. 1997. Our Biosphere. Excellence in Ecology Series 10. Ecology Institute, Oldendorf/Luhe. Germany. 176 pp.

MARRONE, F. \& L. NASELLI-FLORES. 2004. First record and morphological features of $\mathrm{He}$ midiaptomus (Occidodiaptomus) ingens (Gurney, 1909) (Copepoda Calanoida) in Italy. J. Limnol., 63(2): 250-255.

MIRACLE, M. R. 1978. Organització del zooplàncton d'aigua dolça durant un cicle anual: aplicació d'un índex de fluctuacions. Colloquis de la Societat Catalana de Biología, X: 183-193.

MIRACLE, M. R. 1982. Biogeography of the freshwater zooplanktonic communities of Spain. Journal of Biogeography, 9: 455-467.

MIRACLE, M. R., M. SAHUQUILLO \& E. VICENTE. 2008. Large branchiopods from freshwater temporary ponds of Eastern Spain. Verh. Internat. Verein. Limnol., 30(4): 501-505

PÉREZ-BOTE, J. L. 2004. New record of large branchiopods (Branchiopoda, Anostraca, Notostraca and Spinicaudata) from Extremadura (Southwestern Iberian Peninsula). Crustaceana, 77: 871-877.

RIPLEY, B. J. \& M. A. SIMOVICH. 2009. Species richness on islands in time: variation in ephemeral pond crustacean communities in relation to habitat duration and size. Hydrobiologia, 617: 181-196.

SERRANO, L. \& K. FAHD. 2005. Zooplankton communities across a hydroperiod gradient of temporary ponds in the Doñana National Park (SW Spain). Wetlands, 25(1): 101-111.

SOMMER, U., Z. M. GLIWICZ, W. LAMPERT \& A. DUNCAN (1986). The PEG-model of seasonal succession of planktonic events in freshwaters. Arch. Hydrobiol., 106: 433-471.

TAVERNINI, S., G. MURA \& G. ROSSETTI. 2005. Factors influencing the seasonal phenology and composition of zooplankton communities in mountain temporary pools. International Review of Hydrobiology, 90: 356-374.

TAYLOR, B. \& D. L. MAHONEY. 1990. Zooplankton in Rainbow Bay, a Carolina bay pond: population dynamics in a temporary habitat. Freshwat. Biol., 24: 597-612.

TELESH, I. V., M. RAHKOLA \& M. VILJANEN, 1998. Carbon content of some freshwater rotifers. Hydrobiologia, 387/388: 355-360.

THIÉRY, A. (1991). Multispecies coexistence of branchiopods (Anostraca, Notostraca \& Spinicaudata) in temporary ponds of Chaouia plain (Western Morocco), sympatry or syntopy between usually 
allotropic species. Hydrobiologia, 212: 117-136. VASAMA, A. \& P. KANKAALA. 1990. Carbonlength regressions of planktonic crustaceans in Lake Ala-Kitka (NEFinland). Aqua Fenn, 20: 95-102. VALENTÍN, A., B. DIES, C. PEÑA, A. SEBASTIÁN, A. IBARS, E. ESTRELLÉS, J. PRIETO \& F. PUCHE. 2007. Nueva localidades de Riella no- tarsii (Sphaerocarpales) en la Comunidad Valenciana. Bol Soc. Esp. Briol., 30/31: 39-42.

WILLIAMS, D. D. 1997. Temporary ponds and their invertebrate communities. Aquatic Conservation: Marine and Freshwater Ecosystems, 7: 105-117.

ZAHL, S. 1977. Jackknifing an index of diversity. Ecology, 58: 907-913. 